\title{
Announcement
}

\section{"Munich Mycotoxin Scholarship" \\ (Münchner Mykotoxin-Stipendium) \\ for the Promotion of Qualification and Research in the Area of Mycotoxinology}

The Society for Mycotoxin Research (www.mycotoxin.de) is pleased to announce the research scholarship named "Münchner Mykotoxin Stipendium" for the period $2002 / 2003$. The scholarship is endowed with

\section{$€ 10.000,-$}

This scholarship is financed by generous support from the Foundation for Promotion of Microecology and Mycotoxinology (Prof. Dr. Brigitte Gedek and Prof. Dr. Wolfram Gedek) and awarded by the Society for Mycotoxin Research. The scholarship is in remembrance of the scientific work of Profs. Brigitte and Wolfram Gedek during their active academic careers at the Ludwig-Maximilians-University of Munich, Germany.

The scholarship is intended to enable a mycotoxinology-orientated research/study visit (any country; travel and living costs) of a young scientist to a reknowned Institute.

The applicant should not be older than 40 years. Applications must include the following documents:

- Curriculum vitae including previous scientific education and achievements (list of publications),

- detailed description of the scientific programme,

- letter of agreement from the host Institute,

- letters of recommendation from two University Professors.

According to the statutes, the decision about the scholarship is made by a Scientific Committee exclusively on the basis of the scientific quality of the application. The successful applicant is required to report to the scholarship committee about the results and achievements obtained during the research/study visit.

The deadline for submission of applications for the period 2002/2003 is 31 July 2002. Applications should be sent to:

Gesellschaft für Mykotoxinforschung, Kuratorium Münchner Mykotoxin-Stipendium, c/o Herr Dir. u. Prof. Dr. M. Gareis, Institut für Mikrobiologie und Toxikologie, BAFF, E.-C.-Baumann Str. 20, 95326 Kulmbach, Germany 